\title{
Examination of Agricultural Income Inequality in the European Union
}

http://doi.org/10.21272/bel.4(3).36-45.2020

Lívia Benita Kiss, ORCID: https://orcid.org/0000-0001-8864-6874

$\mathrm{PhD}$, Technical Assistant, Szent István University, Georgikon Campus, Keszthely, Hungary

\begin{abstract}
The significant roles of agriculture in the economic development of a country are determinative. It has already made a substantial contribution to the economic prosperity of advanced countries. Its role in the economic development of less developed countries is of vital importance. The share of the population working in agriculture is declining as countries develop. While less than $5 \%$ of the population does in rich countries work in agriculture, more than two-thirds of the people in poor countries. It is predominantly the huge productivity increase that makes this reduction in labor possible. The aim of the study is to provide a comprehensive picture of the situation of agriculture in the European Union from 2010 to 2019, with a particular focus on agricultural income and labor force developments. The number of employed in agriculture has decreased globally (by almost $-14 \%$ ) and in the European Union (by nearly -19\%). The added value of agriculture has grown at a similar rate worldwide (by almost $+22 \%$ ) and in the European Union (by almost $+23 \%$ ). Indicators of agricultural income showed indicator A an increase of $25.56 \%$, indicator B $39.11 \%$ and index C $20.39 \%$ in 2017 compared to 2010. In 2019 the gross value added in agriculture was the most significant in Germany, Spain, France, and Italy. Together, the four countries accounted for $42 \%$ gross value added in agriculture of EU-28. Indicator A, B and C of agricultural income showed in 2019 the most significant positive change in Bulgaria, in Denmark and Romania. Employment in agriculture was the highest in Poland and Romania in 2019. Several reasons can explain the differences in the development of agricultural performance in each European Union country. These reasons can be grouped. On the one hand, the location varies from country to country. Due to their different locations, their climatic, natural and ecological conditions are different. Another important difference is the size of the states. On the other hand, the structure and organization of society are different. Thirdly, the economic situation and status of each country are different.
\end{abstract}

Keywords: Agriculture, Labor, Income, Inequality, European Union.

JEL Classification: E24, J21, J31, J43, Q14.

This work is licensed under a Creative Commons Attribution 4.0 International License

Cite as: Kiss, L.B. (2020). Examination of Agricultural Income Inequality in the European Union. Business Ethics and Leadership, 4(3), 36-45. http://doi.org/10.21272/bel.4(3).36-45.2020.

(C) The Author, 2020. This article is published with open access at Sumy State University.

\section{Introduction}

In recent decades, the population on Earth, at the same time, their needs have started to grow exponentially. Agriculture must keep pace with this growth to ensure the right quantity and quality of food and raw material production. Both natural endowments and social order influence productivity. The aim of the study is to provide a comprehensive picture of the situation of agriculture in the European Union from 2010 to 2019, with a particular focus on agricultural income and labor force developments. Agriculture plays a crucial role in the economy of developing countries, and provides the main source of food, income and employment to their rural populations. According to FAO (2000), it has been established that the share of the agricultural population in the total populace is $67 \%$ that agriculture accounts for $39.4 \%$ of the GDP and that $43 \%$ of all exports consist of agricultural goods. It has become increasingly evident in the last few years that the conception of both economist and policymakers regarding the role of agriculture in economic development has undergone an important evolution. Roughly one quarter of the Earths terrestrial surface is now under cultivation with more land converted to crop production in the 30 years after 1950 than in the previous 150 years. In many regions, including Europe, North America, Australia and recently Brazil, China and India-humanity has also become skillful at raising yields through using inputs like fertilizers, pesticides and organic manures. Yet in many poorer countries with low productivity rates and growing populations, agriculture continues to expand into marginal and fragile lands. In much of sub-Saharan Africa and large parts of Asia - according to estimates 
compiled by the Millennium Ecosystem Assessment (MEA) - almost no highly productive land is left. However, improvements in agriculture and land use are fundamental to achieving food security, poverty alleviation and overall sustainable development. Agriculture in the United States is becoming increasingly trade oriented and trade sensitive. Agricultural trade issues are seen to be much more complex now compared to earlier days. Since the mid-1980s, the value of the dollar has been falling on world currency exchanges and few people (including economists) agree on whether this is good, bad, or no big deal. Congress recently ratified two important trade agreements, the North American Free Trade Agreement (NAFTA) and the Uruguay Round agreement negotiated under the auspices of the General Agreement on Tariffs and Trade (GATT). However, arguments continue over who will win and who will lose under these new trading rules. Fifty years ago, the United States was the largest agricultural exporter, doing about $\$ 3$ billion in sales per year. Six of its top ten customers were in Western Europe; two more - Japan and Canada also were developed countries; India, a food aid recipient, and pre-Castro Cuba were the only developing countries that were major markets (Khanna and Solanki, 2014).

\section{Literature Review}

Role of Agriculture in Economic Development. The significant roles of agriculture in the economic development of a country are as follows:

$>$ In the process of economic development of a country, the agricultural sector plays a strategic role.

$>$ It has already made a significant contribution to the economic prosperity of advanced countries.

$>$ Its position in the economic development of less developed countries is of vital importance.

The role of agriculture in the development of the economy is shown in Figure 1.
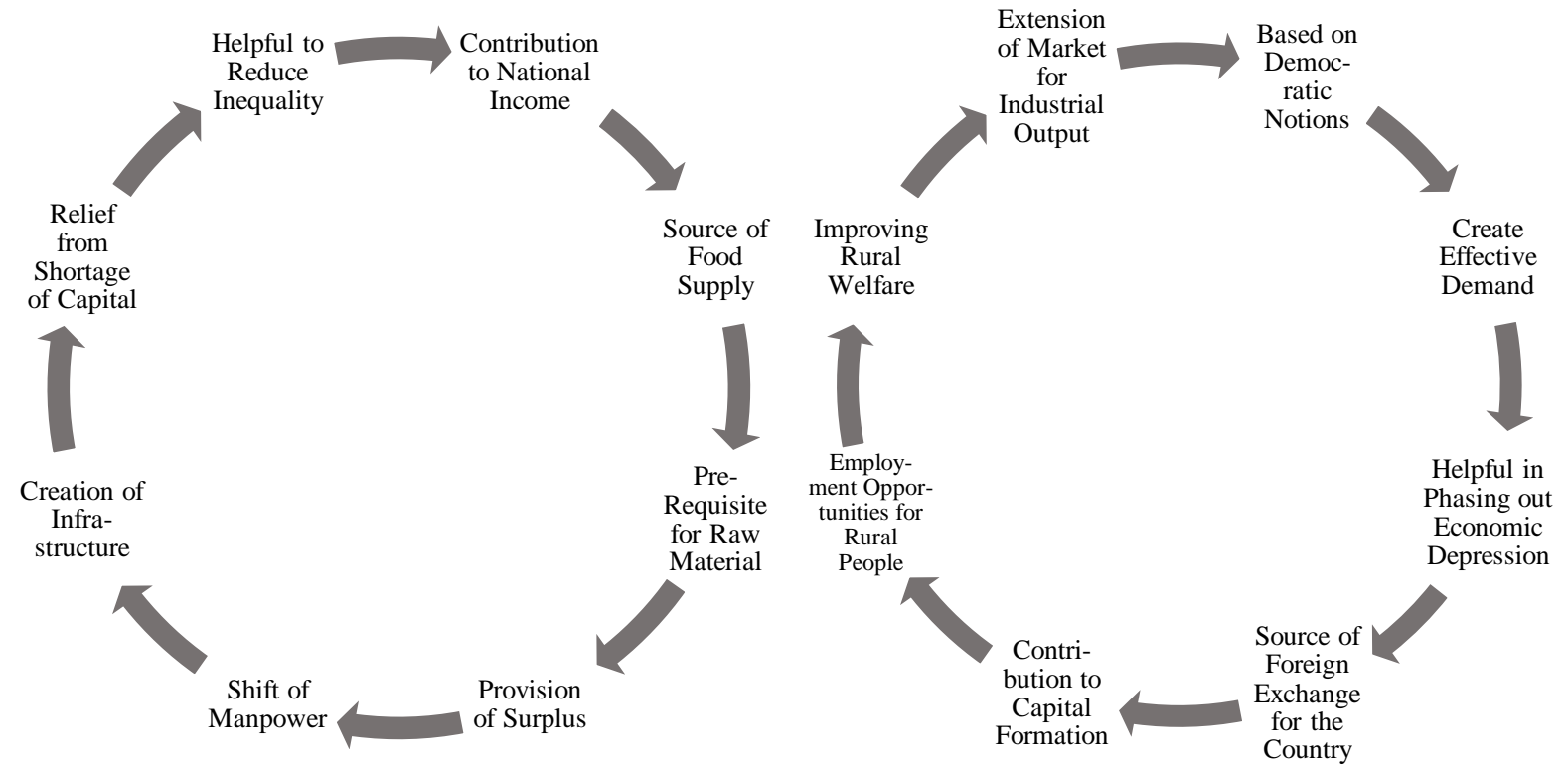

Figure 1. Role of agriculture in economic development

Source: Own editing based on Praburaj (2018)

So, agricultural development is a must for the economic development of a country. As well the developed countries emphasize agricultural development. Agricultural progress is essential:

$>$ to provide food for growing non-agricultural labor force;

$>$ to raw materials for industrial production;

$>$ to save and tax revenue to support the development of the rest of the economy;

$>$ to earn foreign exchange;

$>$ to provide a growing market for domestic manufactures (Praburaj, 2018).

The share of the population working in agriculture is declining as countries develop. Namely, while less than $5 \%$ of the population does in rich countries work in agriculture, more two-thirds of the people in poor countries. It is predominantly the huge productivity increase that makes this reduction in labor possible. Since 1950 we see an overall decline in agricultural employment to comparably low levels of work today (https://ourworldindata.org/employment-in-agriculture). 
Poverty and agriculture. The growth rates of world agricultural production and crop yields have slowed in recent years. It has raised fears that the world may not be able to grow enough food to ensure that future populations are adequately fed. However, this slowdown has occurred not because of shortages of land or water. The demand for agricultural products has also slowed. It is mainly because world population growth rates have been declining since the late 1960s. Reasonably high levels of food consumption per person are now being reached in many countries, beyond which further rises will be limited. But it is also the case that a stubbornly high share of the world's population remains in absolute poverty. So lacks the necessary income to translate its needs into sufficient demand. The growth in the agricultural sector plays a crucial role in improving the profits of poor people by providing farm jobs and stimulating off-farm employment (FAO, 2002).

Few theoretical propositions are more controversial in the literature on income inequality than the ideas of Simon Kuznets (1955). Income inequality increases during the early stages of industrialization, according to Kuznets, as a small segment of the labor force is employed in the industrial sector. As workers continue to migrate to the higher-wage parts of the national economy, however, these lofty levels of inequality eventually decrease. Perhaps most controversially, based on these observations, Kuznets would famously assert, albeit, with some personal skepticism and doubt, that income inequality would decline into the foreseeable future with further economic development and industrialization. Researchers grew a new body of evidence that returned strong support for the aptly named Kuznets Inverted-U hypothesis (Chenery and Syrquin, 1975; Ahluwalia, 1976; Adelman and Morris, 1978; Williamson and Lindert, 1980). An equally large body of literature directly contradicted Kuznets's contentions by the 1980s, as income inequality began to increase in advanced industrial societies (Bluestone and Harrison, 1982; Harrison and Bluestone, 1988; Bluestone, 1990; Levy and Michel, 1991; Levy and Murnane, 1992).

The rise of income inequality in postindustrial societies is driven by the changing returns to skill in the new economy. Over the years, many observe that. They are referred to as skilled-biased technological change. This argument is based on the premise that the computerization of work enhances the demand for non-routine cognitive skills thereby increasing the wages of educated employees (Levy and Murnane, 1992; Krueger, 1993; Katz, 2000; Autor et al., 2003; Autor and Dorn, 2010; Black and Spitz-Oener, 2010; Acemoglu and Autor, 2011). Similarly, according to the empirical research, inequality is no longer driven by the transfer of labor from agriculture to industry, but by the wide variation of earnings between skilled and unskilled workers. It is traditionally referred to as the service sector (Nelson and Lorence, 1988; Chevan and Stokes, 2000; Kim and Sakamoto, 2008; Moller et al., 2009; Lee et al., 2011). Figure 2 shows a stylized illustration of the cycle of inequality hypothesis with three trends of relevance for the distribution of national income. The left-hand side depicts the agricultural-industrial transition from the mid-1800s to the mid-1900s that occurred in rich countries.

Observable here is the classical Inverted-U pattern of rising inequality. During the nascent stages of industrial development, the broken line, and the eventual decline of difference with the maturation of this process. It is the definite trend that Kuznets saw in the data during the mid-1900s. It is important to note that this timing is a generalization that only applies to Western countries. Other wealthy nation-states experienced these transitions at a much later point in time. The top of Figure 1 shows the general shift from a good- to a serviceproducing economy. This shift to a service-producing economy is what, in turn, stimulated a renewed upsurge of income inequality in postindustrial societies. The mid- to late-20th century is defined by the migration of labor out of industry toward the labor-intensive service and knowledge sector. But equally drastic during this time is the outflow of workers from agriculture (Kwon, 2014). 


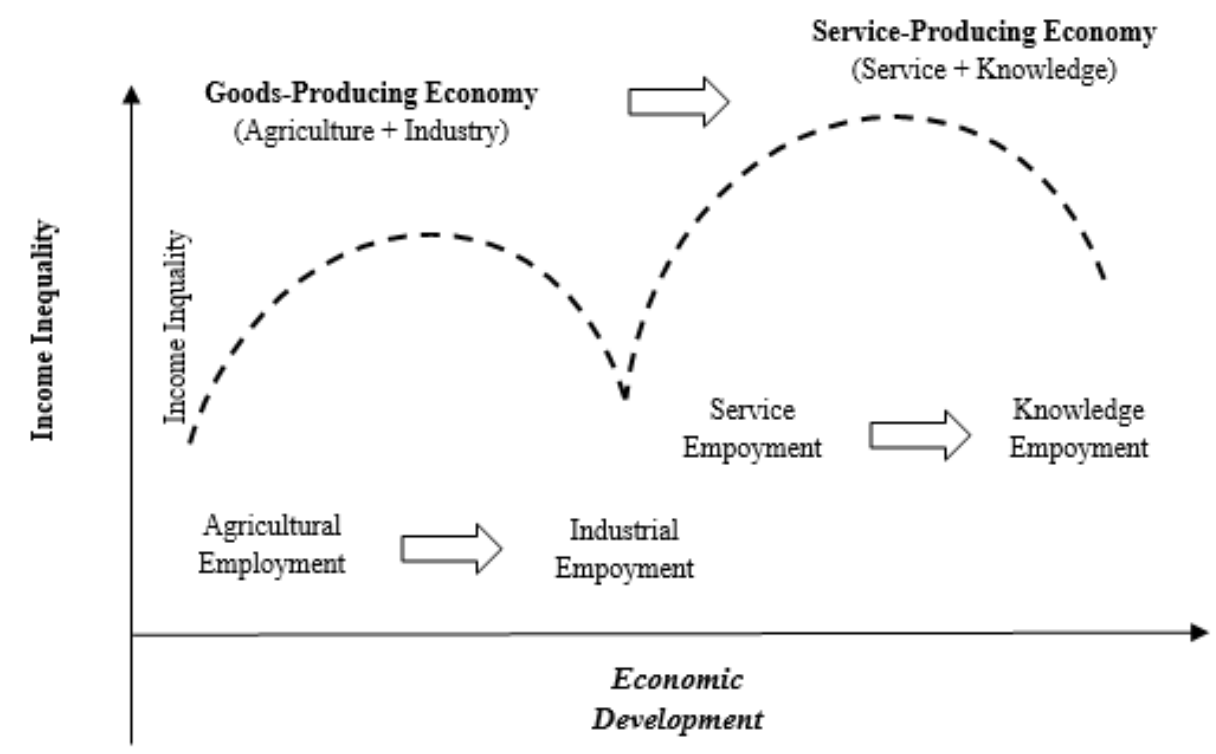

Figure 2. Employment transitions and the cycle of income inequality

Source: Kwon (2014)

Agriculture in the World. Figure 3 shows the agriculture, forestry and fishing value-added in \% of GDP between 2012 and 2018 in the World. A polynomial trend of degree 3 can be fitted to the point diagram. The lowest value added in \% of GDP was provided by the surveyed sector in 2017, while the highest in 2018 . The 2017 was one of the driest and hottest years.

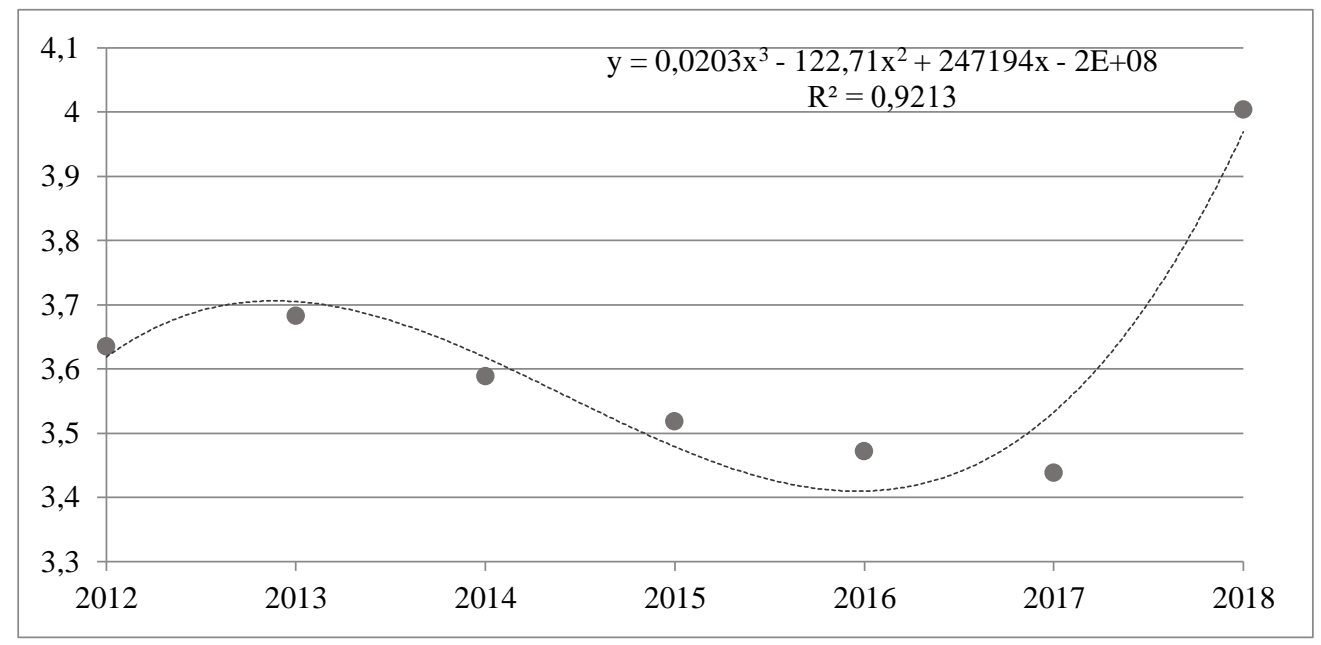

Figure 3. Agriculture, forestry and fishing value added, \% (\% of GDP)

Source: Own editing based on World Bank (2020)

Figure 4 shows the agriculture, forestry and fishing value-added in constant 2010 US\$ between 2012 and 2019 in the World. An increasing linear trend can be fitted to the point diagram. From 2012 to 2019, the value added of the examined sector increased by almost $22 \%$. 


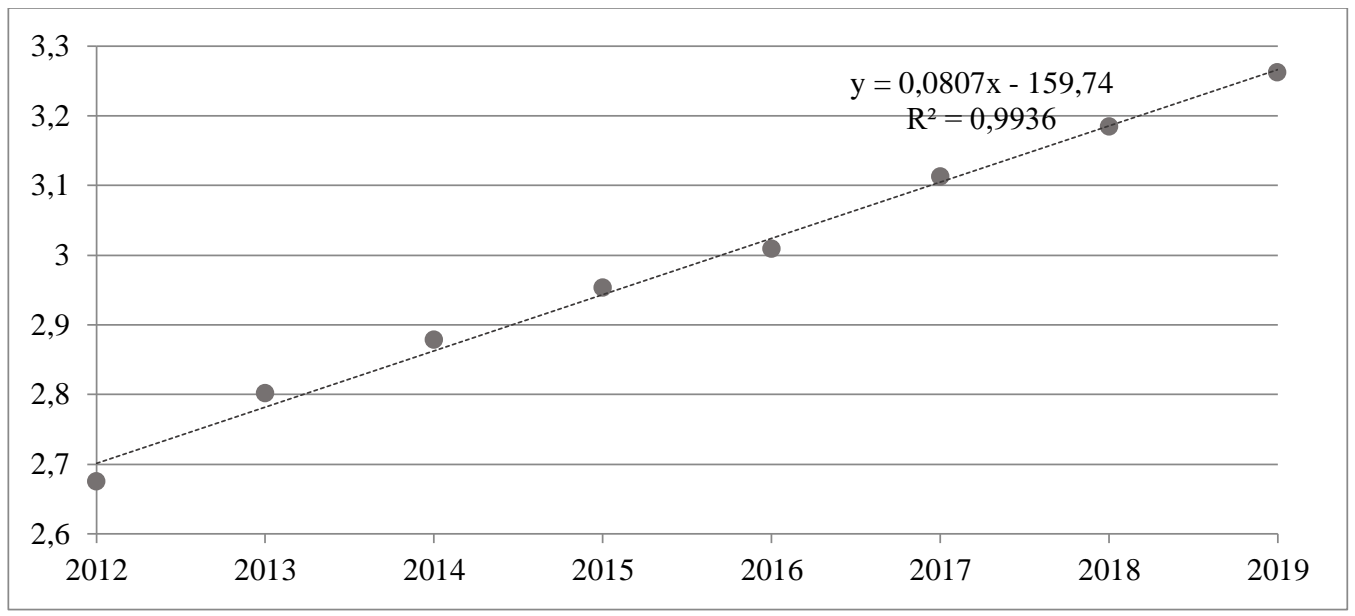

Figure 4. Agriculture, forestry, and fishing, value added, trillion (constant 2010 US\$)

Source: Own editing based on World Bank (2020a)

Figure 5 shows the employment in agriculture in \% of total employment between 2012 and 2019 in the World. A decreasing linear trend can be fitted to the point diagram. Thus, the number of agricultural employees showed a linear decreasing trend during the period under review. From 2012 to 2019, the number of employees in the examined sector decreased by almost $14 \%$.

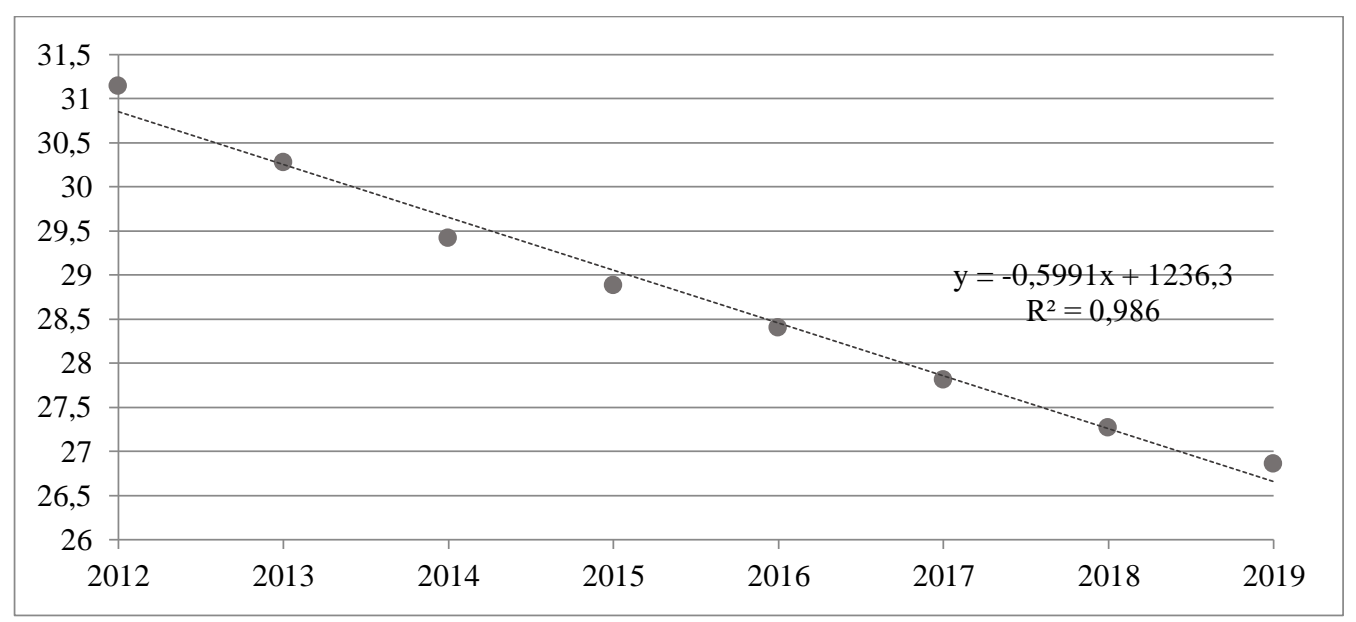

Figure 5. Employment in agriculture, \% (\% of total employment)

Source: Own editing based on World Bank (2020b)

\section{Methodology and Research Methods}

The aim of the study is to provide a comprehensive picture of the situation of agriculture in the European Union from 2010 to 2019, with a particular focus on agricultural income and labor force developments. Table 1 summarizes in the study examined databases and indicators, as well as analysis instruments and methods. Data from Eurostat, the Food and Agriculture Organization and the World Bank were used. The study examined three indicators, which are: agricultural value added, agricultural income, and employment in agriculture. Analysis instruments were the Excel program and GRETL software. Time series and cluster analyzes were used.

Table 1. Examined databases, indicators and analysis instruments and methods in the study

\begin{tabular}{|c|c|}
\hline Examined databases & $\begin{array}{ll}> & \text { Eurostat } \\
> & \text { World Bank Group (WB) } \\
> & \text { Food and Agriculture Organization (FAO) } \\
\end{array}$ \\
\hline Examined main indicators & $\begin{array}{ll}> & \text { value added of agriculture } \\
> & \text { agricultural income } \\
& \text { employment in agriculture }\end{array}$ \\
\hline Analysis instruments & $\begin{array}{ll}> & \text { Excel program } \\
> & \text { GRETL software }\end{array}$ \\
\hline Analysis methods & $\begin{array}{l}>\text { time series analysis } \\
>\text { cluster analysis }\end{array}$ \\
\hline
\end{tabular}

Source: Own editing 


\section{Results}

Table 2 shows the number of farms and the utilized agricultural area (hectare) in the European Union. According to the latest data (2016), the number of farms in the European Union is close to 10500000 . The utilized agricultural area is more than 173000000 hectares.

Table 2. Farm indicators, 2016

\begin{tabular}{|c|c|c|}
\hline \multirow{2}{*}{ EU-28 } & Farm (number) & Utilized agricultural area (hectare) \\
\cline { 2 - 3 } & 10467760 & 173338550 \\
\hline
\end{tabular}

Source: Own editing based on Eurostat (2020)

Figure 6 shows the average economic size of the farm holding sin European Union in 2016 (EU-28=100, based on the average farm's standard output to the EU-28 average, by NUTS 2 regions). There were 64 regions across the EU where the average standard output per farm was at least five times as high as the EU-28 average (at least EUR 174 000). It is shown by the darkest shade in Figure 6. These regions were in Germany, the Benelux Member States, the United Kingdom, France, and Czechia. In the Netherlands (eight), in Germany (six) and Denmark (one) were the average farm size was at least ten times as high as the EU-28 average. In ZuidHolland, the region had the highest level of standard output per farm (EUR 680 700). It was nearly 20 times the EU-28 average (Eurostat, 2019).

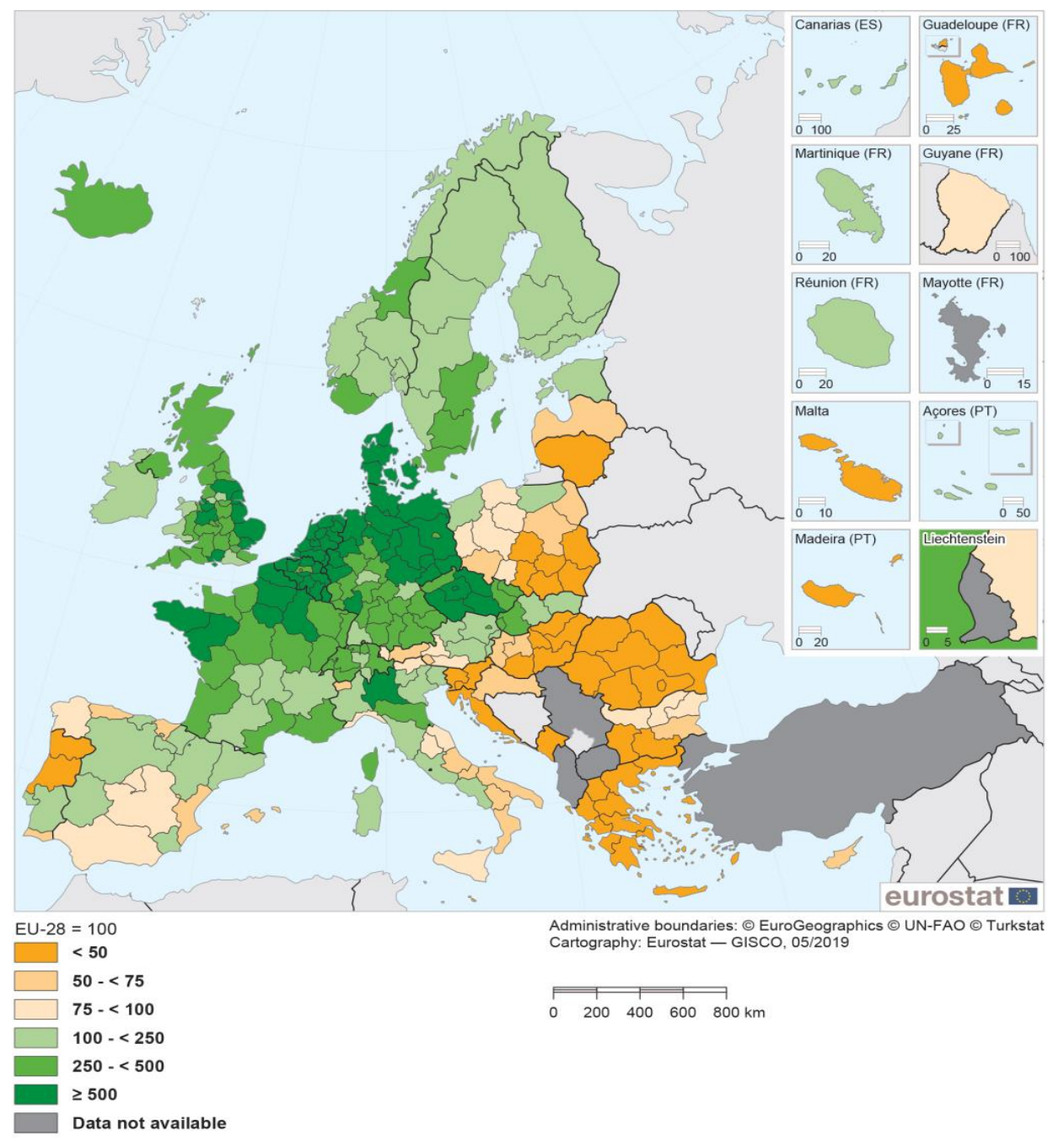

Figure 6. Average economic size of farm holdings, 2016

Source: Own editing based on Eurostat (2019)

Figure 7 shows the gross value of the agriculture at basic prices from 2010 to 2019 in EU-28. The gross value added of agriculture in the EU-28 has shown steady but uneven growth. The years 2017 and 2019 stood out from the examined period. Gross value added in agriculture increased by more than $22 \%$ from 2012 to 2019. 


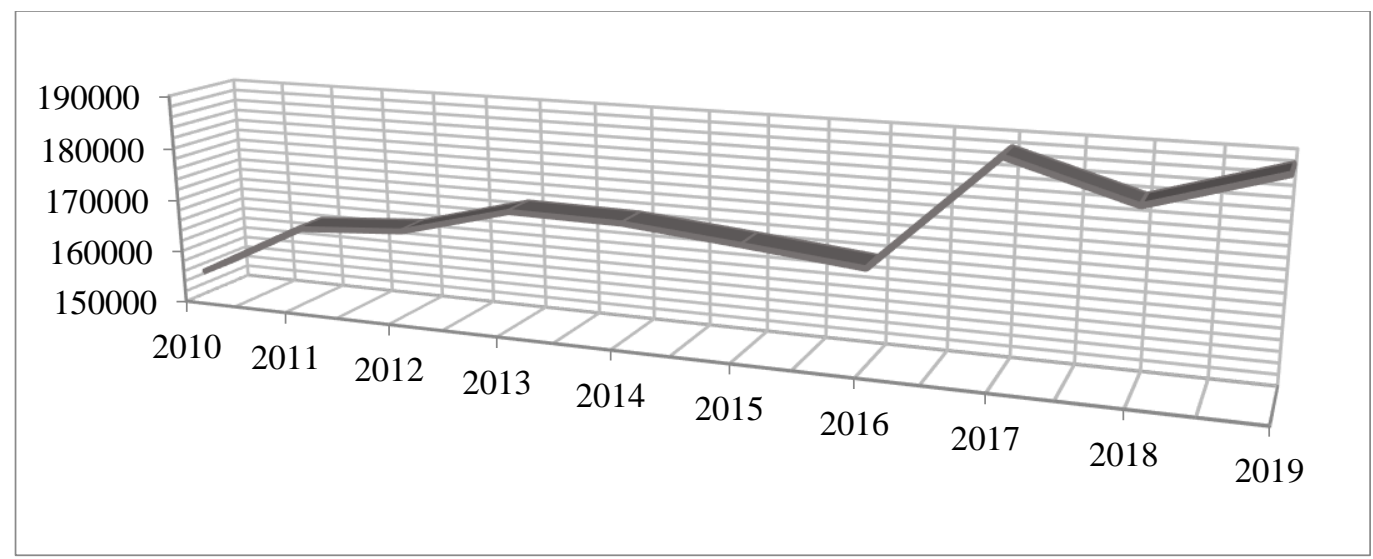

Figure 7. Gross value added of the agriculture (at basic prices, million Euro)

Source: Own editing based on Eurostat (2020a)

Figure 8 shows the changes of agricultural income from 2010 to $2019(2010=100)$ in EU-28. The meaning of indicator A is index of the real income of factors in agriculture per annual work unit. Indicator B is index of real net agricultural entrepreneurial income, per unpaid annual work unit. The meaning of indicator $\mathrm{C}$ is net entrepreneurial income of agriculture. 2017 stands out from the examined period. Indicator A showed an increase of $25.56 \%$, indicator B $39.11 \%$ and indicator C $20.39 \%$ in 2017 compared to 2010.

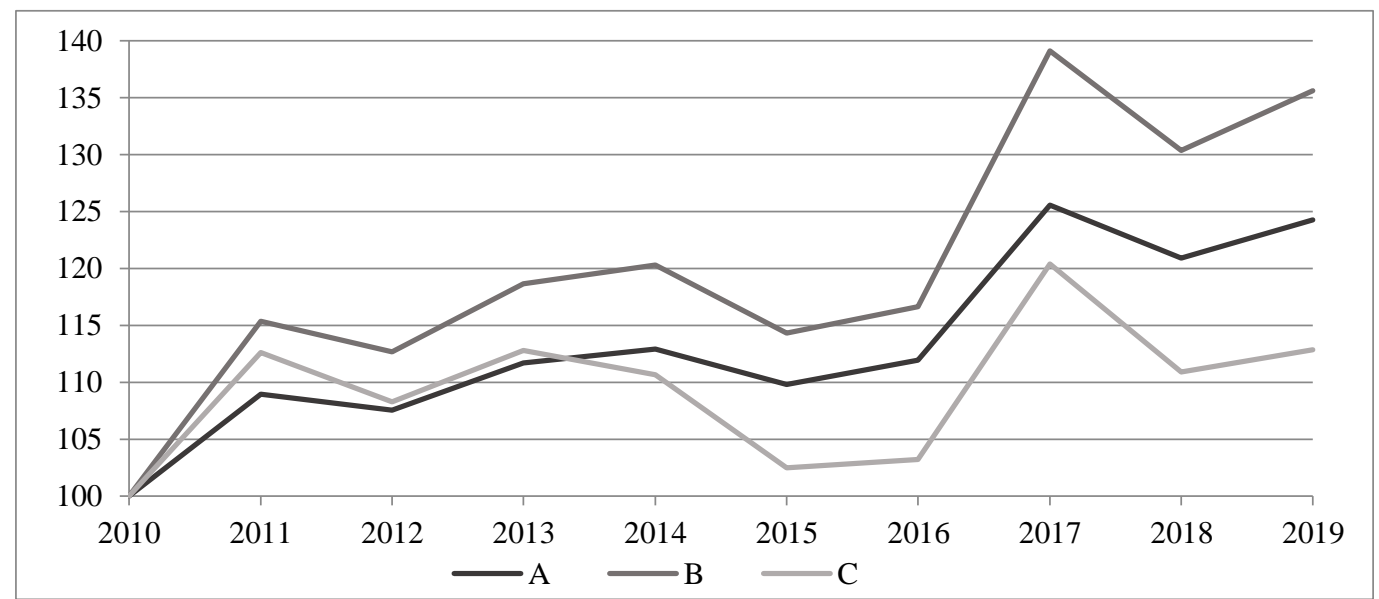

Figure 8. Economic accounts for agriculture - agricultural income, \% (indicators A, B, C; index 2010=100) Source: Own editing based on Eurostat (2020b)

Figure 9 shows the employment in agriculture from 2010 to 2019 in EU-28. The number of employed in agriculture has been steadily declining in the EU-28, in line with the global trend. This decrease from 2012 to 2019 was almost $19 \%$.

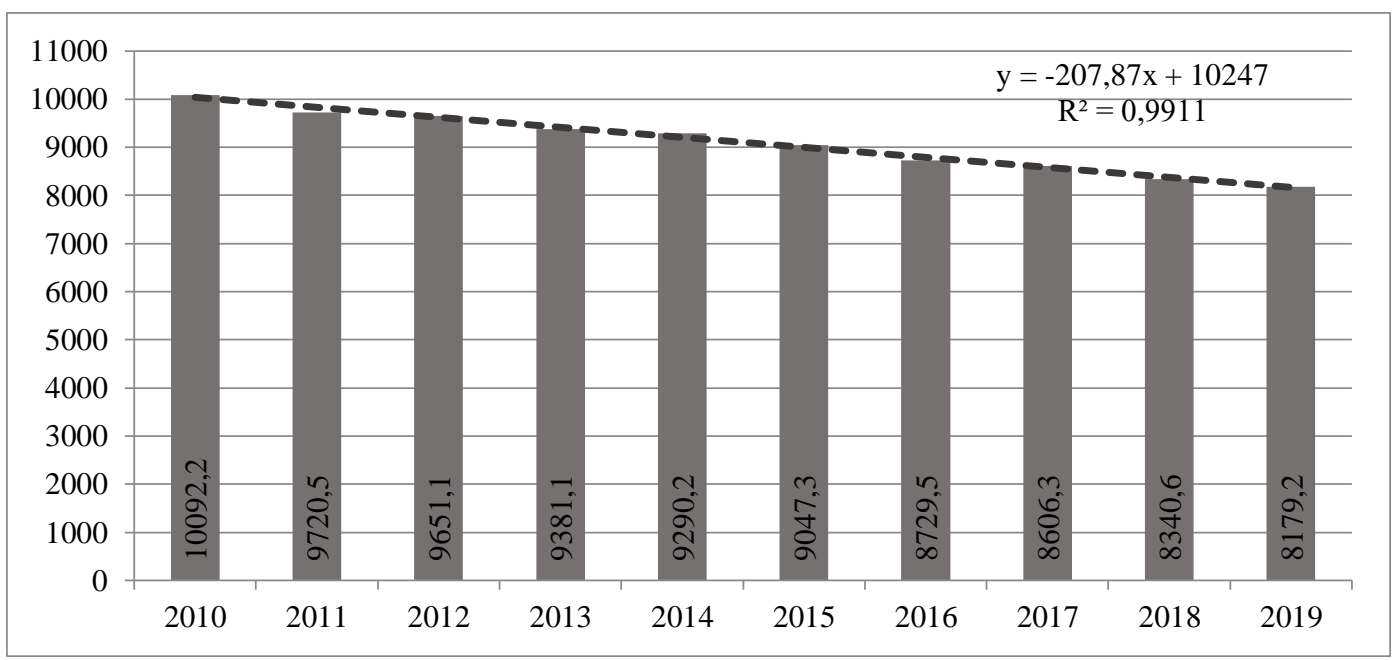

Figure 9. Employment in agriculture (from 15 to 64 years, thousand)

Source: Own editing based on Eurostat (2020c) 
Table 3 summarizes the main examined indicators in the study in EU-28 member states. The values of the examined indicators were divided into four clusters. The largest possible value of the clusters was marked with an increasingly darker color.

Table 3. Clusters of main indicators in EU-28 member states, 2019

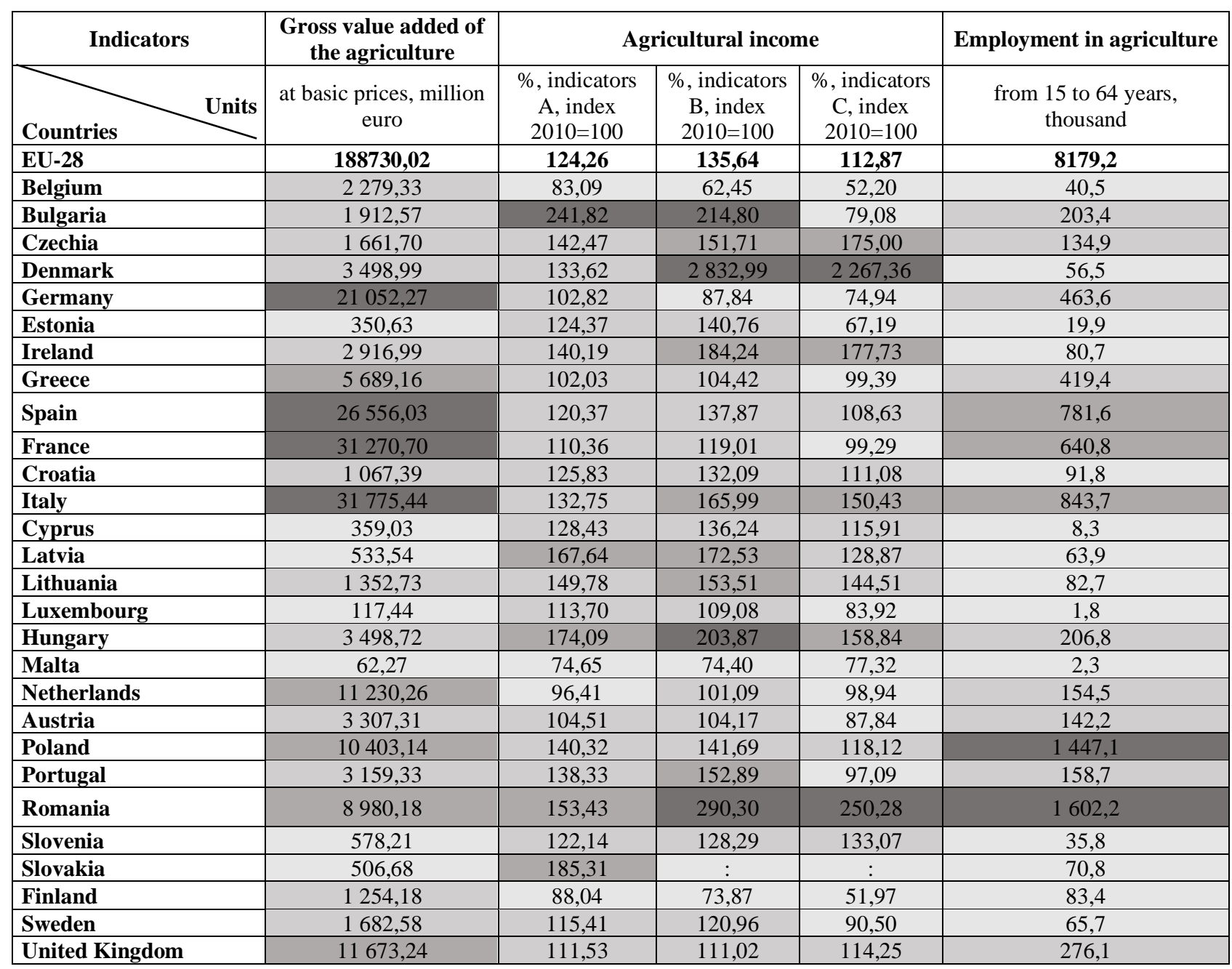

Source: Own editing based on Eurostat (2020a, 2020b, 2020c)

The gross value-added in agriculture was the most significant in Germany, in Spain, France, and Italy. Together, the four countries accounted for $42 \%$ gross value added in agriculture of EU-28. Indicators A, B and $\mathrm{C}$ of agricultural income showed the most significant positive change in Bulgaria, Denmark, and Romania. Employment in agriculture was the highest in Poland and in Romania in 2019.

\section{Conclusions and Discussions}

The number of employed in agriculture has decreased globally (by almost -14\%) and in the European Union (of nearly -19\%). The added value of agriculture has grown at a similar rate worldwide (by almost $+22 \%$ ) and in the European Union (by almost $+23 \%$ ). Indicators of agricultural income showed in 2017 compared to 2010:

$>$ indicator $\mathrm{A}$ an increase of $25.56 \%$,

$>$ indicator $\mathrm{B}$ an increase of $39.11 \%$,

$>$ indicator $\mathrm{C}$ an increase of $20.39 \%$.

In 2019 the gross value added in agriculture was the most significant in Germany, Spain, France and Italy. These are the most important and developed agricultural countries in the EU. Together, the four countries accounted for $42 \%$ gross value-added in agriculture of EU-28. Indicators A, B, and C of agricultural income showed in 2019 the most significant positive change in Bulgaria, in Denmark and Romania. Employment in agriculture was the highest in Poland and in Romania in 2019. Most people employed in agriculture are in countries with developing agriculture. Several reasons can explain the differences in the development of agricultural performance in each European Union country. These reasons can be grouped. 
On the one hand, the location varies from country to country. Due to their different situations, their climatic, natural and ecological conditions are different. Another critical difference is the size of the states. On the other hand, the structure and organization of society are different. Thirdly, the economic situation and status of each country are different.

Funding. There is no funding for this research.

\section{References}

1. Acemoglu, D., \& Autor, D. (2011). Skills, tasks and technologies: Implications for employment and earnings. In: Ashenfelter O and Card DE (eds), Handbook of Labor Economics, Volume 4b. Amsterdam: Elsevier, 1043-1072. DOI:10.1016/S0169-7218(11)02410-5.

2. Adelman, I., \& Morris, C.Y. (1978). Growth and impoverishment in the middle of the nineteenth century. World Development, 6, 245-273. https://doi.org/10.1016/0305-750X(78)90107-9.

3. Ahluwalia, M.S. (1976). Income distribution and development: Some stylized facts. American Economic Review, 66, 128-135.

Available at: https://econpapers.repec.org/article/aeaaecrev/v_3a66_3ay_3a1976_3ai_3a2_3ap_3a128-35.htm.

4. Autor, D., Levy, F., Murnane, R.J. (2003). The skill content of recent technological change: An empirical exploration. Quarterly Journal of Economics 118(4), 1279-1333. https://doi.org/10.1162/003355303322552801.

5. Autor, D., \& Dorn, D. (2010). Inequality and specialization: The growth of low-skill service jobs and the polarization of the U.S. labor market. MIT Working Paper. Available at: http://ftp.iza.org/dp4290.pdf.

6. Black, S.E., \& Spitz-Oener, A. (2010). Explaining women's success: Technological change and the skill content of women's work. Review of Economics and Statistics 92(1), 187-194. https://doi.org/10.1162/rest.2009.11761.

7. Bluestone, B. (1990). The great U-turn revisited: Economic restructuring, jobs, and the redistribution of earnings. In: Kasarda JD (ed.) Jobs, Earnings, and Employment Growth Policies in the United States. Boston, MA: Kluwer, 7-43. Available at: https://link.springer.com/chapter/10.1007/978-94-009-2201-3 2.

8. Bluestone, B., \& Harrison, B. (1982). The Deindustrialization of America: Plant Closings, Community Abandonment, and the Dismantling of Basic Industries. New York: Basic Book. Available at: https://doi.org/10.1002/hrm.3930220413.

9. Chenery, H., \& Syrquin, M. (1975). Patterns of Development, 1950-1970. London: Oxford University Press. Available at: https://documents.worldbank.org/en/publication/documentsreports/documentdetail/482491468328816108/patterns-of-development-1950-1970.

10.Chevan, A., \& Stokes, R. (2000). Growth in family income inequality, 1970-1990: Industrial restructuring and demographic change. Demography, 37, 365-380. DOI 10.2307/2648048.

11.Eurostat (2019). Agriculture statistics at regional level. Available at: https://ec.europa.eu/eurostat/statisticsexplained/index.php/Agriculture_statistics_at_regional_level.

12.Eurostat (2020). Farm indicators by agricultural area, type of farm, standard output, legal form and NUTS 2 regions. https://appsso.eurostat.ec.europa.eu/nui/show.do?dataset=ef_m_farmleg\&lang=en.

13.Eurostat (2020a). Gross value added of the agricultural industry - basic and producer prices. Available at: http://appsso.eurostat.ec.europa.eu/nui/show.do?dataset=tag00056\&lang=en.

14.Eurostat (2020b). Economic accounts for agriculture - agricultural income (indicators A, B, C). Available at: https://appsso.eurostat.ec.europa.eu/nui/show.do?dataset=aact eaa06\&lang=en.

15.Eurostat (2020c). Employment by sex, age and economic activity. Available at: https://appsso.eurostat.ec.europa.eu/nui/submitViewTableAction.do.

16.FAO (2002). World agriculture: towards 2015/2030. Summary report. FOOD AND AGRICULTURE ORGANIZATION OF THE UNITED NATIONS Rome, 2002. Available at: http://www.fao.org/3/ay3557e.pdf.

17.Harrison, B., \& Bluestone, B. (1988). The Great U-Turn: Corporate Restructuring and the Polarizing of America. New York: Basic Books. Available at: https://econpapers.repec.org/article/cupjechis/v_3a49_3ay_3a1989_3ai_3a01_3ap_3a247-248_5f00.htm.

18. Katz, L. (2000). Technological change, computerization, and the wage structure. In: Brynjolfsson E and Kahin B (eds) Understanding the Digital Economy: Data, Tools, and Research. Cambridge: MIT Press, 217-244. Available at: https://scholar.harvard.edu/files/lkatz/files/technological change computerization and the wage structu re.pdf. 
19.Khanna, N., \& Solanki, P. (2014). Role of agriculture in the global economy. 2nd International Conference on Agricultural \& Horticultural Sciences. Agrotechnol, 2(4), 221. http://dx.doi.org/10.4172/21689881.S1.008.

20.Kim, C.H., \& Sakamoto, A. (2008). The rise of intra-occupational wage inequality in the United States, 1983 to 2002. American Sociological Review, 78, 129-157. DOI: 10.1177/000312240807300107.

21.Krueger, A.B. (1993). How computers have changed the wage structure: Evidence from microdata, 1984-1989. Quarterly Journal of Economics, 108, 33-60. https://doi.org/10.2307/2118494.

22.Kuznets, S. (1955). Economic growth and income inequality. The American Economic Review, 45(1), 1-28. Available at: http://gabriel-zucman.eu/files/teaching/Kuznets55.pdf.

23.Kwon, R. (2014). Employment transitions and the cycle of income inequality in postindustrial societies. International Journal of Comparative Sociology, 55(5), 404-428. https://doi.org/10.1177/0020715214561133.

24.Lee, C.S., Kim, Y.B., Shim, J.M. (2011). The limit of equality projects: Public-sector expansion, sectoral conflicts, and income inequality in postindustrial economies. American Sociological Review, 78(1), 100-124. https://doi.org/10.1177/0003122410396195.

25.Levy, F., \& Michel, R.C. (1991). The Economic Future of American Families: Income and Wealth Trends. Washington, DC: Urban Institute Press. https://doi.org/10.1002/pam.4050110324.

26.Levy, F., \& Murnane, R.J. (1992). U.S. earnings levels and earnings inequality: A review of recent trends and proposed explanations. Journal of Economics Literature, 30, 1333-1381. Available at: https://econpapers.repec.org/article/aeajeclit/v_3a30_3ay_3a1992_3ai_3a3_3ap_3a1333-81.htm.

27.Moller, S., Alderson, A., Nielsen, F. (2009). Changing patterns of income inequality in U.S. counties, 19702000. American Journal of Sociology, 114(4), 1037-1101. DOI: 10.1086/595943.

28.Nelson, J.I., \& Lorence, J. (1988). Metropolitan earnings inequality and service sector employment. Social Forces, 67, 492-511. DOI:10.1093/sf/67.2.492.

29.Praburaj, L. (2018). Role of Agriculture in the Economic Development of a Country. Shanlax International Journal of Commerce, 6(3), 1-5. DOI:10.5281/zenodo.1323056.

30.Williamson, J.G., \& Lindert, P.H. (1980). American Inequality: A Macroeconomic History. New York: Academic Press.

Available at: https://scholar.google.com/citations?user=4SSn1AIAAAAJ\&hl=en\#d=gs_md_citad\&u=\%2Fcitations\%3Fview_op\%3Dview_citation\%26h1\%3Den\%26user\%3D4SSn1AIAAAAJ\%26citati on for view\%3D4SSn1AIAAAAJ\%3Au-x6o8ySG0sC\%26tzom\%3D-120.

31.World Bank (2020). Employment in agriculture (\% of total employment) (modeled ILO estimate). Available at: https://data.worldbank.org/indicator/SL.AGR.EMPL.ZS.

32.World Bank (2020a). Agriculture, forestry, and fishing, value added ( $\%$ of GDP). Available at: https://data.worldbank.org/indicator/NV.AGR.TOTL.ZS.

33.World Bank (2020b). Agriculture, forestry, and fishing, value added (constant 2010 US\$). Available at: https://data.worldbank.org/indicator/NV.AGR.TOTL.KD. 